\title{
AN EXPERIMEN'T IN LEARNING A FOREIGN LANGUAGE
}

\author{
By Wal,er LibBy, Ph. D., Northwestern University
}

During recent years the question of how foreign languages may best be taught has been more than once submitted to investigation of a more or less strictly scientific sort. One might mention in this connection Conradi's study of 1905, in which he showed how poor may be the Latin vocabulary of pupils who have been taught Latin one or more years by the usual defective methods. Then, in 1906, Schuyten published his investigation in reference to the learning of foreign words - German, French, and English-in which it was shown that the ability to recall the vernacular word on the presentation of the foreign word is frequently two and three times greater than the ability to recall the foreign word on the presentation of the vernacular. In this same year W. A. Lay, in his periodical on experimental pedagogy, attacked the problem of direct and indirect language instruction by his method of experiment, research and statistics. In 1908, Prof. O. Steine1 published his work on grammar instruction on a physiological basis; while, at the beginning of that year, Prof. E. J. Swift put on record an experiment in the teaching of Spanish carried on under his direction by Mr. William W. Hall, of St. Louis.

No one who stops to think of the amount of time and money consumed in the teaching and learning of foreign languages in our secondary schools, and our so-called institutions of higher learning (in which a large part of the curriculum is given up to the teaching of elementary foreign language), can doubt the importance of the matter with which these investigations concern themselves. It was with the hope of contributing something to problems arising in language instruction that the experiment here recorded was undertaken.

The special purpose of the study was to discover the relative value of making the word or the short sentence the unit in modern language instruction for different types of learners. Naturally other matters, worthy of the consideration of all language instructors, were brought to attention. In the conduct of the experiment we aimed at preserving as far as possible the classroom conditions usual in high school and college, with the important deviation that each exercise lasted only twenty minutes. 
The procedure was to place before the members of a class of ten in experimental pedagogy an exercise in Italian consisting of ten short sentences of approximately five words each and ten detached words, $i$. e., about sixty words in all. None of the class had previously studied Italian, though, as we shall see in detail later, all had studied some foreign language. On the first two occasions the exercises were written on the blackboard; for all the other tests the exercises were typewritten and put before each student. During twenty minutes the Italian was translated, read aloud, written out by the members of the class, and otherwise learned and taught. Eight exercises were given in all. On the fifth occasion a nine-line quotation was substituted for the short sentences; the passage was a very impressive one from the Inferno. Again, at the seventh exercise, it was thought well to vary the monotony by substituting for the sentences eleven lines from an opera. This song and examples of the sentences and words will be given later. An interval of one week elapsed from the beginning of one exercise till the beginning of another, except that there was an interval of two weeks between the sixth exercise and the seventh. A certain procedure was adhered to so far as rigidity did not interfere with the necessary conditions of good teaching, such as the avoidance of boredom, the maintenance of interest, and respect for the individuality of the students. It is intended later to compare the results of other procedures with the results of the pedagogical method here employed. We used the means that seemed likely to lead to the most marked success.

Each exercise was begun on Monday morning, and, as already stated, the students had the words and sentences before them for a space of twenty minutes. On Wednesday, at the expiration of forty-eight hours, they were asked to write down all that they had retained. Then the Italian was once more placed before them and they were asked to write out a translation. Data were thus secured for a comparison of their powers of free reproduction with their powers of recognition, recall through association, etc. During the progress of the experiment the learning process was discussed in class, and in addition the students made two written introspections, one at the time of the fifth exercise, and the other five weeks after the last exercise.

About the close of the semester, four weeks after the eighth exercise, all the Italian sentences and words were once more submitted and translations again obtained. This was a crucial part of the experiment and gave evidence, as we shall see, of the superiority of the short sentence over the word as the unit of modern-language instruction. The success of the mem- 
bers of the class in learning the exercises was also compared with their previous record in language-study, college standing, general ability, etc. Naturally, therefore, the experiment throws light on the learning process in general, and not merely on the specific question of method, which it was the initial purpose of the investigation to answer.

Table I shows the results of the first weekly test. It seems to call for separate treatment, because it was given to the class without much explanation of what was required of them. This manner of presentation was intentional. It discovered the native powers of retaining images, and furnished a basis of comparison of subsequent work in which the will to excel played a more important part. The letters in the table represent the members of the class, of whom B, F, and $G$ were men, and the others women. All were seniors in college except $\mathrm{G}$, who was a graduate, $\mathrm{C}$, who was a junior, and $\mathrm{H}$, a sophomore. The first column of figures represents the number of Italian words recalled from the sentences and separate words after an interval of two days. The second column of figures represents the value in per cent. of the translation of the sentences at the same time, while the last column represents the value in per cent. of the translation of the separate words.

TABLE I

\begin{tabular}{c|c|c|c}
\hline \hline & $\begin{array}{c}\text { Free } \\
\text { Reproduction }\end{array}$ & $\begin{array}{c}\text { Translation of } \\
\text { sentences }\end{array}$ & $\begin{array}{c}\text { Translation of } \\
\text { words }\end{array}$ \\
\hline A & I4 & 86 & 85 \\
B & II & 85 & 80 \\
C & Io & 56 & 85 \\
D & 9 & 63 & I00 \\
E & 8 & 70 & 70 \\
F & 5 & 40 & 90 \\
G & I & 40 & 60 \\
H & II & 90 \\
I & absent & - & - \\
J & absent & - & - \\
\hline
\end{tabular}

One finds here at the outset a considerable correspondence between free reproduction and ability to translate the sentences. G, who was inferior in the power of direct recall to $\mathrm{F}$, and equalled him in the translation of the sentences, shows marked superiority in the later studies, where his maturity and perseverance make themselves felt. The differences between C, D, and E do not call for elaborate comment, but D, as she said, waked up towards the end of the twenty minutes to the fact that a test in memory was in progress, and applied her attention with characteristic energy to the translation. E, 
as she later recognized, was greatly aided in translation by a special ability to associate the parts of the English equivalent. She wrote, "In translation if I could remember what one or two of the words meant I could recall the translation of the whole sentence." This ability was particularly noticeable in this first exercise, where the seven sentences attempted were translated perfectly.

Table II shows the improvement in free reproduction during the two months the experiment was carried on.

TABLE II

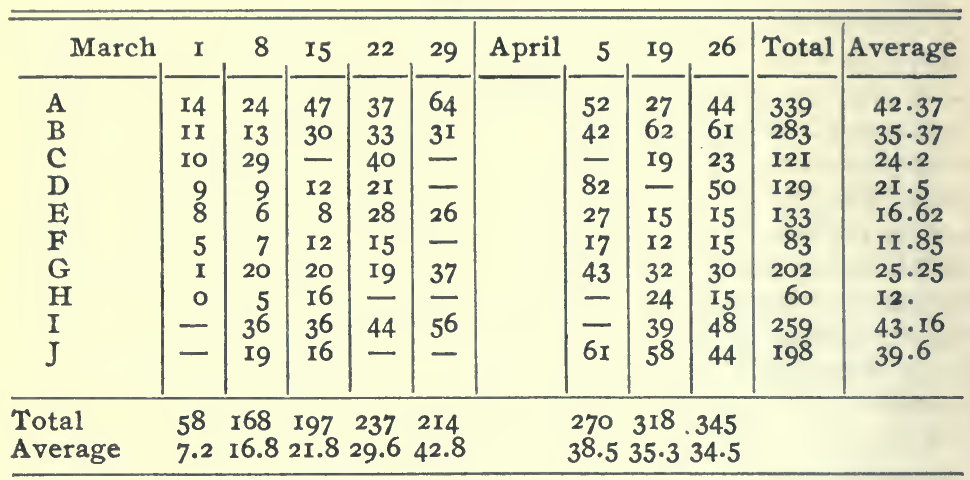

Even these data, limited as they are, serve to show the dependence of progress in language-learning on the improvement in free imagery. How much success in the exercises resulted from conscious efforts to make the images of the Italian more vivid is apparent from the written accounts by the class of their methods of study. A, whose aptitude for this work was marked throughout the experiment reports, "I think my method was almost entirely by association of the Italian in half visual, half auditory imagery with the English in auditory (with a very much smaller degree of visual)." B, who made steady and brilliant progress, was very clear as to how he learned. "In learning the Italian," he wrote, "whenever I could hear the sentences and words spoken, they became fixed in my mind; during the latter part of the experiment, however, I had obtained some idea of the 'sound' of the language, and so just the sight of the words was often enough to fix the sound in my mind." I transcribe the seventh exercise and this student's reproduction of it after an interval of two days.

Morir!si pura e bella! Morir per me d'amoreDegli anni tuoi nel fiore,
Morir!si pura e bella, Morir per me d'amore Degli anni tuoi nel fiore, 
T'avea il cielo per l'amor creata. Ed io t'uccido per averti amata!

Vedi?di morte 1'angelo

Radiante a noi si appressa-

Ne adduce eterni gaudii

Sovra i suoi vanni d'or,

Su noi già il ciel dischiudesi-

grosso
dimorare
cacio
zanzara
moto
piangere
curiosità
lutto
raggio
braccio

Fuggir la vita!

Fuggir la vita.

T'avea il cielo per l'amor creata, Ed io t'uccidopper averti amata.

Vedi?di morte 1
Radiante a noi
Ne adduce etern
Sovra i suoi van
Su noi gia il ciel
grosso
dimorare
cacio
zanzara
moto
piangere
curiositá
luto
raggio
braccio

Vedi?di morte l'angelo Radiante a noi si appressa$\mathrm{Ne}$ adduce eterni gaudii Sovra i suoi vanni d'or.

On this same occasion all that $F$ could recall were the following unconnected words : nauzaza dimorari, braccio moriri, bella, leggio, amore grosso, moto, vedi, morte, gaudii curiosita, pura.

That such differences exist in the powers of free reproduction of two classmates working under the same general conditions will surprise all perhaps except experienced teachers. One feels that in the learning of foreign language the vividness of the imagery is something that should not be neglected.

F writes, "Visual imagery played the heaviest part in my process of learning Italian." He notices, however, that he moves his lips in learning the exercises, and concludes that motor imagery may have played some part. C reports that all her memory depended on visual imagery. "If I could not recall the place in the sentence and on what part of the page the word was, it was hopeless to try and recall the word." In spite of this consciousness of location it is remarkable that C's memory was rather for detached words. Her exercises were lacking altogether in the continuity that marked the work of the auditory-minded B, already quoted, and that of the motorminded J, given below.

D says, "When the work was put on the board, I read a sentence several times, and then shut my eyes and repeated it until I could see it clearly in images." She tried for a while writing the words down, "but it did not make much difference, in fact it retarded my memory of them all, for it took more time and made two kinds of images,- - printed and handwritten. It is much easier for me to retain one image." Quite in contrast with this experience is that of $\mathrm{J}$, who gives a striking account of her method of learning. "It is almost im- 
possible for me to memorize any thing without writing it down, in fact, it is impossible for me to learn any hard lesson that has to be memorized in any order of ideas, without a pencil in my hand." "The first sets of Italian sentences, which I tried to learn by visualization or by an effort of memory alone, were entirely new to me when we were re-examined in them, whereas the others, which I had learned by writing them down, were as old friends." She thinks she could never remember which words follow which. Within the sentence, as the subjoined exercise shows, her memory for order is remarkably good when she writes the work out. Once more speaking of her way of learning things she writes, "The proportion of them and the feeling of them impress me more than anything else; I can't describe it, but it is n't the look of a thing alone."

Quando arriva il treno a Roma?

Viene con me il più presto possibile.

Non feci nessuna attenzione.

Quanto debbo pagare pel servizio?

Come stà?Stà bene?Si, Signora.

Preparatemi un bagno caldo.

E Lei già stato a Venezia?

Il letto non è preparato.

Farò tutti i miei sforzi.

Aspetto risposta per il portatore.

Arrosto
cervello
insalata
uora
frutto
pomidoro
pesce
colazione
cena
riso

Comme stà?Stà bene?Si, signora. Preparatemi unbagno caldo.

Faro tutti i miei sforzi.

Quanto debbo pagare pel servizio? Quando arriva il treno a Roma?

Il letto non è preparato.

Feci non nessuna attenzione.

E lei gia a stato Venezia?

Vieni con me il più possibile presto.

Aspetto risposta per il portatore.

uova
cena
colazione
frutto
insalata
cervello
arrosto
riso
pomidoro

This was the sixth exercise, but $J$ had studied only two of the previous sets of sentences and words, and had not done remarkably well in them. This splendid performance, after two twenty-minute lessons in Italian, indicates the value of discovering one's own best method of learning, perhaps previously to any extended work in a new study. J's marked improvement in translation, shown in Tables III and IV further justifies our procedure, which emphasized the importance of gaining a vivid image of the foreign words and sentences.

$\mathrm{H}$, whose record was by no means encouraging, seemed to herself to fail because the circumstances of the recitation made it difficult for her to use the imagery most congenial to her. She is ear-minded, but no drill was given in the foreign sounds, 
and after the first few exercises no special pains were taken to pronounce the Italian, as the class did not seem to demand it.

$E$ says, "In learning the words and sentences I found that I could learn them better when I would spell them in a whisper so that I could hear them." "I wrote the words also, and spelled and pronounced them as I wrote, and I found this very helpful." G writes, "I tried working on the Italian alone and committing it by rhythm, and auditory, visual, and motor imagery, but I found the method unsatisfactory." "The most satisfactory was to learn the Euglish first and then get the Italian; ask about any particularly hard part as this seemed to fix the words; and then as quickly as I could after class reproduce all I could remember in writing and commit it thoroughly." Another member of the class, I, "learned the exercises by visual and auditory imagery, more easily when the two were combined."

The Tables that follow, III, IV, V, and VI, serve to show how these learners of various types succeeded in learning the translation of the Italian words and sentences, and how their power of retaining the latter compared with that of retaining the former. Table III gives the percentage values of the translation of the sentences made by the class two days after the first sight of each exercise.

TABLE III

\begin{tabular}{|c|c|c|c|c|c|c|c|c|c|c|}
\hline & & & & & & & & & Total & Average \\
\hline A & 86 & 95 & 100 & 100 & 100 & 88 & 100 & 100 & 769 & 96.12 \\
\hline B & 85 & 80 & 100 & 100 & 100 & 100 & 100 & 100 & 765 & $95.6 \mathrm{r}$ \\
\hline C & $5^{6}$ & 92 & - & 90 & - & - & 95 & 92 & 425 & 85 \\
\hline D & $6_{3}$ & 78 & 75 & 93 & - & 98 & - & 100 & 507 & $84 \cdot 5$ \\
\hline $\mathrm{E}$ & 70 & 95 & 65 & 78 & $8 \mathrm{r}$ & 67 & $5^{8}$ & 95 & 609 & 76.12 \\
\hline F & 40 & 60 & 70 & 67 & - & 80 & 70 & 90 & 477 & 68.14 \\
\hline G & 40 & 72 & 80 & 95 & 100 & 100 & 100 & 100 & 687 & 85.87 \\
\hline $\mathrm{H}$ & II & 50 & 25 & - & - & - & 70 & 90 & 240 & 48 \\
\hline I & - & 86 & 60 & 82 & 75 & - & 100 & 100 & 503 & 83.83 \\
\hline $\mathrm{J}$ & - & 74 & 60 & - & - & 95 & 100 & 100 & 429 & 85.8 \\
\hline
\end{tabular}

Total $\begin{array}{llllllll}45 & 782 & 635 & 705 & 456 & 628 & 793 & 967\end{array}$ Average $\quad 56.378 .270 .5$ 88. I 91.289 .7 88.1 96.7

In conjunction with this must be considered Table IV, which gives the results in percentages of the translation of the words during the first eight weeks of the experiment.

We do not find so marked the teudency to improve in the translation of the words as in the translation of the sentences. The fourth table seems more subject to fluctuations, perhaps because it is sometimes possible to guess the meanings of the 
TABLE IV

\begin{tabular}{|c|c|c|c|c|c|c|c|c|c|c|}
\hline & & & & & & & & & Total & Average \\
\hline $\mathbf{A}$ & 85 & 100 & 100 & IOO & 100 & 88 & 100 & 100 & 773 & 06.62 \\
\hline B & 80 & 98 & 90 & 100 & 100 & 100 & 100 & 100 & 768 & \\
\hline C & 85 & 95 & - & 95 & - & - & 80 & 80 & 435 & 87 \\
\hline D & 100 & 85 & 50 & 90 & - & 98 & - & 100 & 523 & 87.16 \\
\hline $\mathbf{E}$ & 70 & 95 & 65 & 100 & 60 & 90 & 60 & 60 & 600 & 75 \\
\hline F & 90 & 60 & 50 & 45 & - & 100 & 60 & 30 & 435 & 62.14 \\
\hline G & 60 & 65 & 60 & 90 & 100 & 100 & 60 & 90 & 625 & 78.12 \\
\hline $\mathrm{H}$ & 90 & 75 & 40 & - & - & - & 100 & 30 & 335 & 67 \\
\hline I & - & 95 & 75 & 90 & 100 & - & 100 & 100 & 560 & 80 \\
\hline $\mathrm{J}$ & - & 75 & 80 & - & - & 100 & 100 & 100 & 455 & 9I \\
\hline
\end{tabular}

Total $\quad 660 \quad 843 \quad 610 \quad 710 \quad 460 \quad 676 \quad 760 \quad 790$

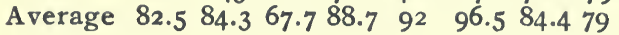

words. Moreover, what is most important for our experiment, on this first translation the averages, both collective and individual, are higher in the fourth table than in the third; $i . e$, there is greater success in recognizing the words than in recognizing the sentences. If we combine the records for the words and sentences, we find that A, B, C, etc., secured the following percentages respectively : $96,95,86,85,75,65,8 \mathrm{I}$, $57,8 \mathrm{r}, 88$.

Four weeks after the eighth exercise, as already stated, all the exercises were resubmitted. The results are recorded below. Table $\mathrm{V}$ represents the translation of the sentences, Table VI that of the words.

TABLE V

\begin{tabular}{|c|c|c|c|c|c|c|c|c|c|}
\hline & & & & & & & & & Total \\
\hline A & 86 & 100 & & 95 & 100 & 100 & 100 & 100 & $68 I$ \\
\hline B & 67 & 79 & & 65 & 95 & 80 & 100 & 80 & 566 \\
\hline C & 29 & 84 & - & 67 & - & - & 80 & 74 & 334 \\
\hline $\mathrm{D}$ & 39 & 54 & & & & & & & \\
\hline $\mathrm{E}$ & 44 & 34 & & 50 & 55 & 50 & 55 & 74 & 362 \\
\hline $\mathrm{F}$ & 22 & 25 & 30 & 37 & - & 57 & 20 & 30 & $22 \mathrm{I}$ \\
\hline G & 50 & 62 & 22 & 80 & 90 & 82 & 82 & 78 & 546 \\
\hline $\mathrm{H}$ & 34 & 12 & I 5 & - & - & - & 50 & I 2 & II 3 \\
\hline I & - & 75 & 78 & 75 & 75 & - & 98 & 100 & 501 \\
\hline $\mathrm{J}$ & - & 71 & 36 & - & & 95 & IOO & 50 & 302 \\
\hline
\end{tabular}

Comparing the totals of Table $\mathrm{V}$ with the comparable sums from Table III, we find that the best students most nearly approximated their former record (A even surpassing hers), while the students who had made the poorest records in the first place with the exercises now fell the furthest below their 
TABLE VI

\begin{tabular}{l|l|l|l|l|l|l|l|l|l|l}
\hline \hline \\
\hline A & 90 & 92 & & 90 & 100 & 85 & 98 & 100 & 655 \\
B & 85 & 90 & & 75 & 90 & 98 & 80 & 55 & 573 \\
C & 34 & 90 & & 60 & - & - & 40 & 60 & 284 \\
D & 90 & 80 & & & & & & & Total \\
E & 50 & 71 & & 70 & 40 & 70 & 30 & 10 & 341 \\
F & 80 & 50 & 10 & 20 & - & 50 & 30 & 20 & 260 \\
G & 60 & 78 & 40 & 40 & 50 & 70 & 25 & 35 & 398 \\
H & 40 & 72 & 40 & - & - & - & 40 & 20 & 212 \\
I & - & 65 & 60 & 70 & 70 & - & 70 & 70 & 405 \\
J & - & 60 & 36 & - & - & 100 & 55 & 35 & 286 \\
\hline
\end{tabular}

own former performances. The following figures represent in percentages the relation of the marks taken on the final test to those taken previously. A-ror, B-85, C-78, D-E-64, $\mathrm{F}-46, \mathrm{G}-79, \mathrm{H}-47, \mathrm{I}-99, \mathrm{~J}-70$. Making a similar comparison of Table VI with Table IV, we find again that the superior students came more nearly to their previous records than did the inferior ones. The following figures represent the relation in percentage of the final test on the words to the result on the first test: $\mathrm{A}-97, \mathrm{~B}-84, \mathrm{C}-65, \mathrm{D}-, \mathrm{E}-62$, $\mathrm{F}-59, \mathrm{G}-63, \mathrm{H}-60, \mathrm{I}-72, \mathrm{~J}-62$.

Again, placing together the results of these two comparisons, we have a means of measuring the ability to retain sentences with the ability to retain detached words.

$\begin{array}{lrl}\text { A } & \text { IOI } & 97 \\ \text { B } & 85 & 84 \\ \text { C } & 78 & 65 \\ \text { D } & & \\ \text { E } & 64 & 62 \\ \text { F } & 46 & 59 \\ \text { G } & 79 & 63 \\ \text { H } & 47 & 60 \\ \text { I } & 99 & 72 \\ \text { J } & 70 & 62\end{array}$

Here there is seen to be an advantage in retaining the sentences except in the case of two students. These were, it is interesting to note, as far as success in learning the exercises is concerned, the two weakest students in the class. The better students recognized expressly the advantages of studying languages by sentences rather than by words. A, in order to learn the detached words, first made sentences of them. On this point $B$ writes, "As to the detached words and the complete sentences or rather ideas, I found it much easier to memorize the latter. At times it was necessary to resort to some purely mechanical method in order to retain the separate 
words, such methods as arranging them in a sentence (when it really became learning sentences or ideas), arranging them in alphabetical order," etc. Still another student, I, writes, "In learning the separate words, I found, at the time of our review, that I could not recall some of them, while it was not difficult to recall the sentences entire; in other words, I could learn a whole sentence and remember it much better than one isolated word. So were I to learn any new language, I should certainly do so, not by cramming a lot of unrelated words into my brain, but by words connected in meaning in sentences."

The range of individual differences was as marked a feature of the final test as of the rest of the experiment. Below are given the translations by $\mathrm{A}$ and $\mathrm{H}$ of the eighth exercise four weeks after it was first presented.

\begin{tabular}{l} 
Exercise VIII \\
\hline Il treno è in ritardo. \\
La supplico di non abbandon- \\
armi.
\end{tabular}

Ha egli scritto qualcosa d'altro?

$\mathrm{Ha}$ avuto la miglior parte.

E superiore alla mia immaginazione.

Il sole mi dà noia

Dove c'è una pensione?

Non è questo troppo caro?

Non avete un libro simile a questo?

E questo il suo più recente lavoro?

legare
edizione
ponderato
sarta
mosca
mano
lato
tirare
molto
pianura

\begin{tabular}{|c|c|}
\hline A's translation & $\begin{array}{c}\text { H's trans- } \\
\text { lation }\end{array}$ \\
\hline $\begin{array}{l}\text { The train is late. } \\
\text { I beg you not to leave } \\
\text { me. } \\
\text { Has he written any- } \\
\text { thing else? } \\
\text { He has the best of it. } \\
\text { It is beyond all my im- } \\
\text { agination. } \\
\text { The sun annoys me. } \\
\text { Where to find a lodg- } \\
\text { ing place. } \\
\text { Is not this too dear? } \\
\text { Have you not a book } \\
\text { like this? } \\
\text { Is this his most recent } \\
\text { work? } \\
\text { bind } \\
\text { edition } \\
\text { heavy-deliberate } \\
\text { dressmaker } \\
\text { fly } \\
\text { hand } \\
\text { side } \\
\text { shoot } \\
\text { much } \\
\text { plane }\end{array}$ & $\begin{array}{l}\text { edition } \\
\text { hesitate } \\
\text { tailor } \\
\text { late } \\
\text { talk }\end{array}$ \\
\hline
\end{tabular}

While A translated all the sentences and all the words with a fair degree of accuracy, $\mathrm{H}$ succeeded with only one sentence and one word among the separate words, and that, edizione, one readily guessed. When you consider the various types of imagery, the various methods of study, and the different powers of retention of the group under examination, you 
realize how complex is the instrument on which the instructor of even a small class attempts to play. Some of these differences are undoubtedly inborn, while others are the result of previous experience.

Swift, in the experiment already referred to, paid special attention to the effect on the learning of Spanish prose composition of previous school work in German and Latin. $\mathrm{He}$ recognized an initial advantage, which did not vanish during the limited time the investigation was in progress, on the part of those who had been taught other languages before taking up Spanish. He does not explain this advantage as the effect of language discipline in general, but says, "It cannot be doubted that the substance of information carried over from Latin or German would give beginners in a new foreign language a decided lead over classmates who were receiving their first introduction to work of this sort." The students in my experiment were conscious of the effect of their previous work in language on their ability to learn Italian. A says, "I keep the English equivalent-and the French or Latin, if that is nearer-in mind." She also made use of all the grammar she could construct for herself from the examples. B writes, "Undoubtedly my experience with other languages helped me greatly, especially Latin and French. At times, except for the spelling, it would seem to me that I was translating Latin or French." In C's exercises I frequently found the French equivalent substituted for the Italian word. She was taking a course in French at the time the experiment was in progress. On the other hand $H$ felt the lack of previous experience in language study and she wrote, "The exercises were hard for me at all times because I have never taken much language work, therefore it is impossible for me to see the derivation of the words, or to associate them with other translations." What she felt she lacked, and what the others were conscious of availing themselves of, was naturally what could be described as "substance of information."

Table VII represents the number of years spent in the study of foreign language by the members of the class at high school and college. The grade of work done at college is indicated by the letters $a, b$, and $c$. The figures following these letters show the number of semester-courses.

A careful consideration of this table reveals that as far as their experience in the study of foreign language is concerned, the members of the class rank as follows: A, B, J, E, C, G, $\mathrm{D}, \mathrm{F}, \mathrm{I}, \mathrm{H}$. To what extent this order corresponds to that of the excellence of the students in the learning of the Italian exercises we shall see more definitely by and by. In the meantime it is manifest that however important imagery may 
TABLE VII

\begin{tabular}{|c|c|c|c|c|c|c|c|c|c|}
\hline & \multicolumn{4}{|c|}{ High School } & \multicolumn{4}{|c|}{ College } & \multirow{2}{*}{ Total } \\
\hline & Greek & Latin & French & German & & Latin & French & German & \\
\hline $\begin{array}{l}\text { A } \\
\text { B } \\
\text { C } \\
\text { D } \\
\text { E } \\
\text { F } \\
\text { G } \\
\text { H } \\
\text { I } \\
\text { J }\end{array}$ & $\begin{array}{r}\text { I } \\
\text { some } \\
\text { I } \\
\text { I }\end{array}$ & $\begin{array}{l}4 \\
4 \\
4 \\
4 \\
3 \\
4 \\
4 \\
2 \\
4 \\
2 \cdot 5\end{array}$ & $\begin{array}{l}3 \\
1\end{array}$ & $\begin{array}{l}I \cdot 5 \\
\text { I. } 5 \\
2\end{array}$ & $\begin{array}{l}2 \\
\text { I } \\
I \\
I \\
2.5\end{array}$ & $\begin{array}{l}\text { a3br } \\
\text { arbI } \\
\text { bIcI } \\
\text { bIcI } \\
\text { a3b2cI }\end{array}$ & $\begin{array}{l}\text { I a2 } \\
2 \text { b4 } \\
2 \text { a2c2 }\end{array}$ & 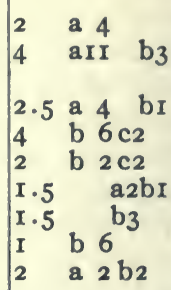 & $\begin{array}{l}\text { I3 yrs. } \\
\text { 10 } \\
8-9 \\
8 \\
9 \\
7 \\
9 \\
5 \\
5 \\
9\end{array}$ \\
\hline
\end{tabular}

be in the learning process, apperception is a factor that cannot be neglected. How far definiteness of imagery depends upon the apperception this is not the place to discuss. I, who is a mature student, knew how to help out her learning by conscious associations; her mind "was always seeking for some comparison with something that had been previously assimilated." She concludes that her "natural method of memorizing is the logical one." G likewise helped out his rather poor imagery by learning the translation and consciously associating the Italian with the English. He made it a point, as we have seen, to ask about sentences that he found it hard to memorize, and to thus form associations by little discussions in class. E was also very conscious of her associative processes. She writes, "The method that I found best in memorizing the Italian was in relating the Italian meaning to the English, and by writing down the Italian and by spelling it out as I wrote it, so that I could hear the sound of the letters and also see the words."

The general college records, inclusive of the foreign language credits, of the members of the class, are given in Table VIII. The figures represent the number of examinations passed, or rather, the number of half-yearly courses taken. The letters at the heads of the column are the grades obtained.

As already stated, $\mathrm{C}$ was a junior, $\mathrm{G}$ a graduate, and $\mathrm{H}$ a sophomore. It is fair to say that the following represents the order of these students as far as their college record is concerned : A, B, J, I, D, G, C, E, F, H. That the order established by their college record is that of their general ability I should hesitate to say. Qualitative rather than quantitative differences are uppermost in mind in making a general comparison of the members of the class. For the grades that 
TABLE VIII

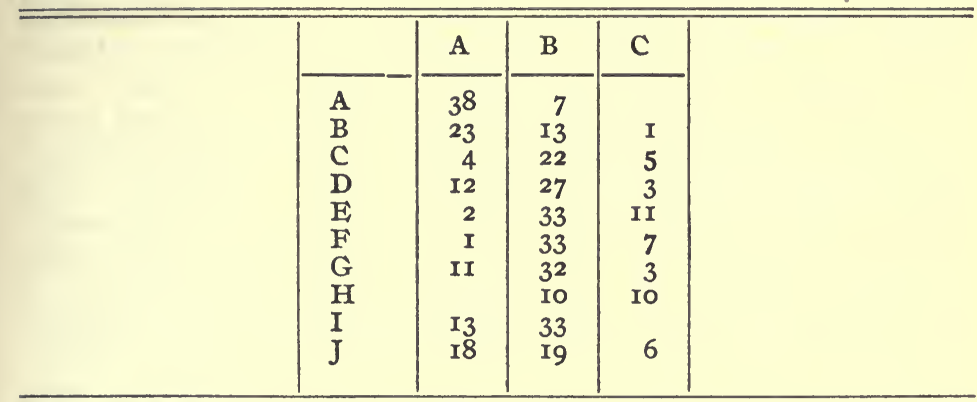

they received in the course in experimental pedagogy, the writing of a thesis rather than the passing of an examination was the decisive thing. As the choice of a subject and the making of the investigation were left largely to the student in each case, their grading might be supposed to afford a clew to their general intelligence and executive ability. I find that the grades, represented this time by numbers, were as follows : $\mathrm{A}-\mathrm{I}, \mathrm{B}-\mathrm{I}, \mathrm{C}-4, \mathrm{D}-\mathrm{I}, \mathrm{E}-3, \mathrm{~F}-3, \mathrm{G}-\mathrm{I}, \mathrm{H}-2, \mathrm{I}-\mathrm{I}, \mathrm{J}-$ I. Nothing, therefore, in the standing finally secured by these students in this course would warrant one in taking exception to the grading obtained in their general college record. Of course in speaking of general ability one naturally asks whether effort and will-power do not at times offset native aptitude. The presence of a steady purpose in some cases and its absence in others cannot well be overlooked. Where the purpose was strong, however, it is noticeable that it led to new methods of study, more conscious associations, and more vivid imagery. The student who felt the lack of motive to learn the exercises, - which lack certainly gave a touch of artificiality to our work but did not lessen its likeness to the usual school drudgery, - failed to find a sufficient incentive to make the preparation of a good thesis worth while, and the college record shows that the impending final examination failed to arouse to energy the latent power one continued to have faith in. The better students good-naturedly took it for granted that the play was worth the pains, or did the work as one of the most brilliant expressed it, "simply from the habit of doing what we are told." Whether the docile or lethargic promises more for the future we shall not now take time to discuss.

A steady effort was made to render the exercises interesting as far as the nature of the work permitted. The introduction of the quotation from Dante in the fifth exercise, and the more difficult song from Aida in the seventh exercise, were intended 
to relieve the monotony, or rather to anticipate it. The effect can be traced in the tables. As a rule, the short sentences were such as might be of value to travellers in Italy. One of the nembers of the class writes, "Sometimes, if there was presented a nice little conversational sentence, I would say it in Italian to my friends-as: Che mi consigliate di fare? Such remained longer by me than the rest." B says on this point, "Some lessons, furthermore, were more readily memorized than others, such, for example, as the selection from the opera, and certain common but very useful sentences, as Il treno è in ritardo, etc. Here it is undoubtedly true that interest plays a very important part in my learning process. Where this feature was lacking, it was necessary to resort to will power ; this was only necessary, however, in two or three cases and then, I believe, interest failed solely from physiological reasons. I found it quite possible to memorize the Italian of every lesson, but the less interesting it was, the greater effort it required." "Of course the shortness of the exercises prevented the interest from flagging." A says, "I doubt whether I could have studied much longer than twenty minutes at a time as hard as I did." This student also notes, "I remember some of the unusual constructions best, because I paid most attention to them. I forgot some of the most natural words and constructions, because they were so natural that I did not pay particular attention to them."

In Table IX a summary is made of the main results of this investigation. By it we are enabled to compare the students at a glance in the following respects: general college record (C. R.), grade in experimental pedagogy determined largely by a thesis ( $T$. ), free imagery of the Italian on the first trial of all (I.), average record in free reproduction after a two days' interval (A. R.), translation of the sentences after a two days' interval ('T. S.), translation of the words after a two days' interval (T. W.), retention of the sentences (R. S.), retention of the words (R. W.), experience in foreign language study (F. L.). For the students' grades in the thesis work only four numbers were used; except in this instance the figures represent the order of excellence in the class.

The investigation increases my confidence in the value of the general college record, and leads me to believe that a study such as this is capable of yielding simple means for determining general ability. The degree of vividness of the imagery, whether it be visual, motor, auditory, or of a mixed type, is a factor of the first importance in the learning process. Subsequent experiment with the exclusive use of this or that type of imagery will determine whether with a heterogeneous class a better average result can be obtained than in this ex- 
periment, in which we aimed at reproducing the classroom conditions as nearly as possible, under the limitations already mentioned.

TABLE IX

\begin{tabular}{l||r|r|r|r|r|r|r|r|r}
\hline \hline & C. R. & T. & I. & A. R. & T. S. & T. W. & R. S. & R. W. & F. L. \\
\hline A & I & I & I & 2 & I & I & I & I & I \\
B & 2 & I & 2 & 4 & 2 & 2 & 3 & 2 & 2 \\
C & 7 & 4 & 3 & 6 & 5 & 5 & 5 & 4 & 5 \\
D & 5 & I & 4 & 7 & 6 & 4 & & & 7 \\
E & 8 & 3 & 5 & 8 & 8 & 8 & 7 & 6 & 4 \\
F & 9 & 3 & 6 & 9 & 9 & 10 & 9 & 8 & 8 \\
G & 6 & I & 7 & 5 & 3 & 7 & 4 & 5 & 6 \\
H & IO & 2 & 8 & IO & IO & 9 & 8 & 7 & IO \\
I & 4 & I & & I & 7 & 6 & 2 & 3 & 9 \\
J & 3 & I & & 3 & 4 & 3 & 6 & 6 & 3 \\
\hline
\end{tabular}

One naturally asks in conclusion what hints for actual classroom work can be gathered from a study of this sort. Would it be wise for the teacher of foreign languages to cast aside dry vocabularies, and to teach words only in their connections? Would it be worth while to construct interesting dictionaries, in which no word would be given without a valuable example of its use? Should we, before plunging into the work of teaching a foreign language, attempt to find out something of the previous experience of the student in language study, and of his characteristic methods of learning? Should we limit the length of the recitation to half an hour? Should the recitation be so conducted as to allow full liberty to individual differences in the learning process? To some of these questions we feel prepared to give a decided answer. For example, our study leads us to sympathize fully with the humorous appeal, in reference to method of study, of one of the best students: "Give me liberty or give me death !" Most of these questions, however, will require for their solution the joint consideration of many theorists and many practical instructors. Meantime it is encouraging to note that the matter of classroom methods is being recognized as accessible to a treatment more promising of definite results than that heretofore employed. A great gain would be made for scientific pedagogy if trained teachers of foreign language could be led more generally to undertake experiments to answer some of the problems that confront them, or even if they could be induced to put on record their more striking successes and the exact procedure by which obtained. At the same time the aim of experimental pedagogy in this as in other fields must be not to ignore nor seek to upset the work of the practical teacher, but 
to submit data for his consideration, to afford a scientific basis for pedagogical skill, and so far as possible to make of general avail the triumphs of pedagogical tact.

\section{REFERENCES}

Conradi, Edward. Latin in the High School. Ped. Sem., 1905, Vol. I2, pp. I-26.

LAX, W. A. Zur experimentellen Untersuchung der Frage der direkten und indirekten Methode im fremdsprachlichen Unterricht. Exper. Pädagogik, 19o6. Vol. 3, pp. 95-ror.

SchuYTeN, M. C. Experimentelles zum Studium der gebräuchlichsten Methoden im fremdsprachlichen Unterricht. Exper. Pädagogik, I906. Vol. 3, pp. 199-210.

STEINEL, O. Der Grammatikunterricht auf physiologischer Grundlage und die grammatisch-syntaktische Veranschaulichung der Sprachen. Kaiserslautern, E. Crusius, I908. $77 \mathrm{p}$.

SwIFT, E. J. Mind in the Making. N. Y., Scribner, 1908. 329 p. See Chapter VIII, Experimental Pedagogy, pp. 244-253. 